${ }^{\bullet}$ Entomologica Fennica. 22 October 2001

\title{
Two new species of Swammerdamia from the southern Ural Mountains and southern Siberia (Lepidoptera: Yponomeutidae)
}

\author{
Jari Junnilainen
}

\begin{abstract}
Junnilainen, J. 2001: Two new species of Swammerdamia from the southern Ural Mountains and southern Siberia (Lepidoptera: Yponomeutidae). Entomol. Fennica 12: 112-118.

Swammerdamia glaucella sp. n. and S. buraetella sp. n. are described on the basis of material collected from the southern Ural Mountains and southern Siberia. S. glaucella occurs in forest steppe slopes and bushy meadows in two generations from the end of May to the beginning of July and late July. The species is widely distributed in southern Russia and the adjacent regions. $S$. buraetella is only known from Buryatia where it seems to favour open steppe habitats. The species occurs in two generations from the end of April to the end of May and in July. Both new taxa differ from their known relatives both externally and on the structures of genitalia. The Russian records of Kessleria caflischiella (Frey, 1880) are discussed.
\end{abstract}

Jari Junnilainen, Mahlapolku 3, FIN-01730 Vantaa, Finland; E-mail: junnilainen@fi.ibm.com

Received 16 February 2000, accepted 7 February 2001

\section{Introduction}

Since the description of the genus Swammerdamia Haworth, 1826, many studies have been conducted concerning this and related genera of small ermine moths in the Yponomeutinae (e.g. Friese 1960, Moriuti 1977, Huemer \& Tarmann 1992). A recent historical review (Gershenson \& Ulenberg 1998) outlines information concerning 231 species classified in 25 genera, including Meyrick's List of Yponomeutidae in Wagner's Lepidopterorum Catalogus (1914). Gershenson \& Ulenberg (1998) recognised eight species of Swammerdamia, six of those belonging to Palaearctic, one to Ethiopian and one to Oriental fauna. In addition, they list eleven species of the closely related Paraswammerdamia, eight of which be- long to Palaearctic, two to Ethiopian and one to Oriental fauna. In the present paper, two new species of Swammerdamia are described based on specimens collected in the southern Urals and widely in southern Siberia and some adjacent regions. One of the species, Swammerdamia glaucella sp. n., has proved to be a widespread and locally abundant species in, e.g. the southern Urals region. Therefore, it is somewhat surprising that this species was not mentioned by Eversmann (1844), which is the most thorough source of information about the Lepidoptera fauna of the southern Ural Mountains. As further discussed in the Remarks under $S$. glaucella below, it seems that the identity of this species has later on been confused with Kessleria caflischiella (Frey, 1880) occurring in the Alps. 


\section{Classification and species descriptions}

The generic classification followed here is based on those of Friese (1960) and Moriuti (1977). The new taxa have been defined from the genus Swammerdamia by the following combination of characters: Adult: Maxillary palpus 1-segmented; tongue developed; forewing rather broad, 11veined with completely fused $\mathrm{M} 3$ and $\mathrm{Cu} 1 \mathrm{~A}$; hindwing 7-veined by fusion of M3 and Cu1A, M1 and M2 separate; abdominal terga spinose. The following characters in the male and female genitalia further support the placement of the new species to Swammerdamia: uncus forming a plate, socii with one spine at apex, tuba analis membranous, sacculus large and defined, transtilla absent, saccus narrow and somewhat dilated anteriorly, aedeagus with distinct cornuti. Lamella postvaginalis with a pair of caudal processes, corpus bursae round, signum usually present. The closely related genus Paraswammerdamia is characterised by the rudimentary uncus, the valva with a conspicuous sacculus and the stout saccus in the males, and the usually well developed caudal processes of the lamella postvaginalis in the females. Sometimes the signum is also absent (e.g. Paraswammerdamia ruthiella Steuer, 1993).

\section{Swammerdamia glaucella sp. $\mathbf{n}$.}

Type material. Holotype: $0^{7}$ (Fig. 1): Russia, southern Urals, Cheliabinsk district, $55^{\circ} 01^{\prime} \mathrm{N} 60^{\circ} 06^{\prime} \mathrm{E}$, $350 \mathrm{~m}$, Miass, Ilmen reserve, 19.VI.1998 J. Junnilainen leg. In coll. J. Junnilainen. Paratypes (166 O'ర $0^{7}, 30$ 우): same data as in holotype: 11 రారా $^{7} 8$ 우; same locality as holotype except: 13.VI.1996 1 ర', 28.VI.1996 5 0'0', 28-29.VI.1996 3 o'రా, 26-27.VI.1997 25 రారా 3 우, 26.VI.1997

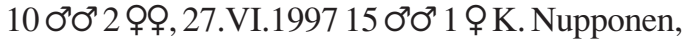
J.-P. Kaitila, J. Junnilainen \& M. Ahola leg.; $53^{\circ} 57^{\prime} \mathrm{N} 59^{\circ} 03^{\prime} \mathrm{E}, 650 \mathrm{~m}$, near Moskovo village, 22.VI.1996 3 ర̛⿱ $^{7}$ K. Nupponen, J.-P. Kaitila, J. Junnilainen \& M. Ahola leg., 26.V.1998 2 రా రా, 18.VI.1998 1 O$^{7}$ T. \& K. Nupponen leg.; Cheliabinsk district, $53^{\circ} 59^{\prime} \mathrm{N} 61^{\circ} 12^{\prime} \mathrm{E}, 250 \mathrm{~m}$, Troizkii

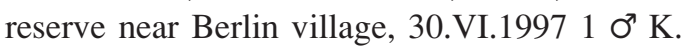

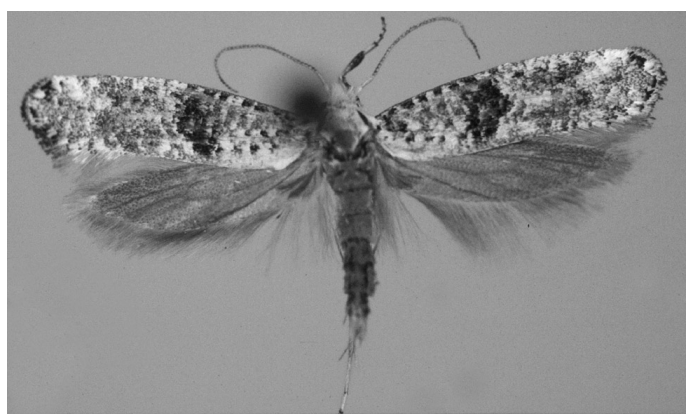

Fig. 1. Swammerdamia glaucella sp. n. ơ holotype.

Nupponen, J.-P. Kaitila, J. Junnilainen \& M. Ahola leg., $53^{\circ} 02^{\prime} \mathrm{N} 62^{\circ} 06^{\prime} \mathrm{E}, 200 \mathrm{~m}$, Ajat river near Nikolaevka village, Sokolovskaja gora,

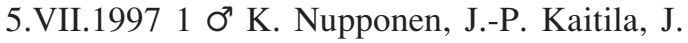

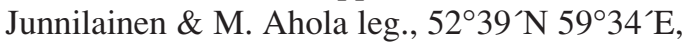
$350 \mathrm{~m}$, Arkaim reserve, near Amurskii village, 14.VI.1996 3 0'0', 15.VI.1996 1 o', 17.VI.1996 1 O’, 14-19.VI.1996 4 రా రా, K. Nupponen, J.-P. Kaitila, J. Junnilainen \& M. Ahola leg., 15.VI.1999 $10^{7}$ T. \& K. Nupponen leg.; Orenburg district, $51^{\circ} 13^{\prime} \mathrm{N} 57^{\circ} 37^{\prime} \mathrm{E}, 350 \mathrm{~m}$, Mednogorsk $20 \mathrm{~km} \mathrm{~S}$ near Kidriasovo village, 28-29.V.1998 4 ơ $0^{\top}, 1$ 우 J. Junnilainen leg., 28.V.1998 6 07రా, 29.V.1998

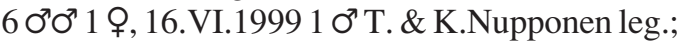
$51^{\circ} 23^{\prime} \mathrm{N} 56^{\circ} 49^{\prime} \mathrm{E}, 130-340 \mathrm{~m}$, Donskoje village $6 \mathrm{~km} \mathrm{~W}$, Mount Verbljushka 30.V.-5.VI.1998 2

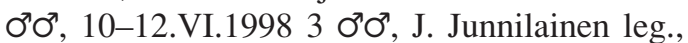

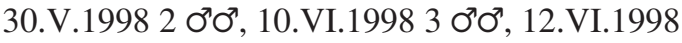
1 o', 15.VII.1998 1 ơ 1 \&, 13.V.1999 1 ơ", 17.VI.1999 $10^{7} 1$ o, 18.VI.1999 2 Ơం $^{7}, 27$. VII.2000 $10^{\circ}$, T. \& K. Nupponen leg., 50 $40-45^{\prime} \mathrm{N} 54^{\circ} 26-$ 28`E, 170-230 m, Pokrovka village $20 \mathrm{~km} \mathrm{~S}$, Chalk hills, 3-7.VI.1998 1 O' J. Junnilainen leg., 5.VI.1998 1 O', 6.VI.1998 1 O', 7.VI.1998 2 0'0", 22.VI.1999 $20^{\prime \prime}, \mathrm{T} . \&$ K. Nupponen leg.; $51^{\circ} 26^{\prime} \mathrm{N}$ 57²6’E, 250 m, Kuvandyk 12 km SE, 15.VI.1998 $10^{7}, 16$. VI.1998 1 Ơ $^{7} 1$ 우 T. \& K. Nupponen leg.; Bashkiria $51^{\circ} 54^{\prime} \mathrm{N} 57^{\circ} 43^{`} \mathrm{E}, 450 \mathrm{~m}$, Sakmara river near Jantyshevo village, 20.VI.1996 $60^{7} 0^{\prime \prime}$, 21.VI.1996 12 Ơం $^{7} 1$ ㅇ, K. Nupponen, J.-P. Kaitila, J. Junnilainen \& M. Ahola leg.; Bashkiria $51^{\circ} 48^{\prime} \mathrm{N}$ $57^{\circ} 05^{\prime} \mathrm{E}, 500 \mathrm{~m}$, Kasmarka river near Bishtiryak village, 13.VII.1998, 1 0', K. Nupponen leg.;

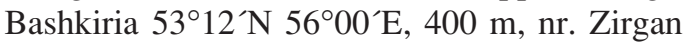




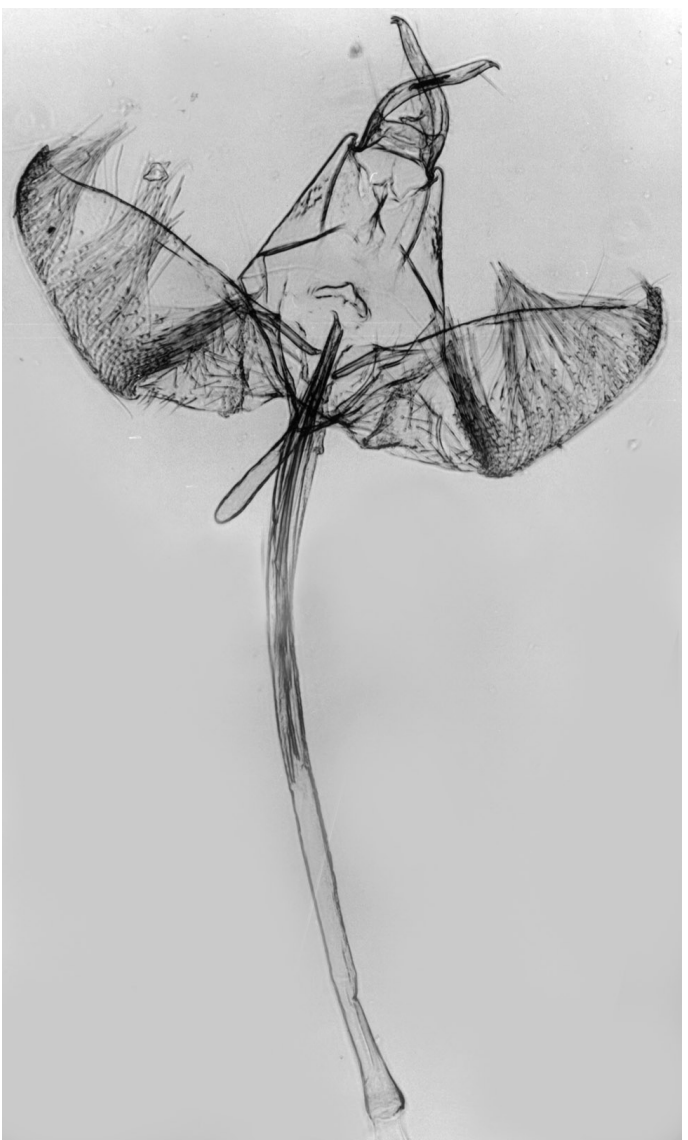

Fig. 2. Swammerdamia glaucella sp. n., ơ genitalia (paratype, Russia S.-Ural, Cheliabinsk distr. Prep. no. $98041001 /$ Junnilainen).

village, 24.VI.1999 $10^{7} 1$ 우 T. \& K. Nupponen leg.; Altai Mts., $51^{\circ} 35^{\prime} \mathrm{N} 85^{\circ} 55^{\prime} \mathrm{E}, 700 \mathrm{~m}$, Katun valley, Ust-Sema village $10 \mathrm{~km} \mathrm{SE}, 23$.VI.2000 2 우 T. \& K. Nupponen leg., SW-Altai, Katun valley, $10 \mathrm{~km}$ W Katanda, 1200 m, 22.VI-8.VII.1983 9 ơ $^{7} 1$ o, exp. Mikkola, Hippa \& Jalava leg.; Novosibirsk oblast, Akademogorodok, 1020.VI.1983 1 ○', exp. Mikkola, Hippa \& Jalava leg.; Tuva rep., $52^{\circ} 04^{\prime} \mathrm{N} 94^{\circ} 22^{\prime} \mathrm{E}, 670 \mathrm{~m}$, Ust-

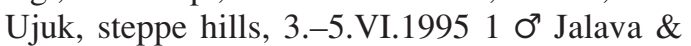
Kullberg leg.; Buryatia, $54^{\circ} 21^{\prime} \mathrm{N} 110^{\circ} 12^{\prime} \mathrm{E}$, Barguzin valley, Upper Kurumkan river, 700 m, mixed forest, 1.VII.1996 $30^{7} 0^{7}$ Jalava \& Kullberg leg.; Mongolia: Tov Aimak, 48²2`N 106² 18`E, 1100 m, 18-23.VI.1997 $10^{7}$ Yu.M. Marusik leg. Kazakhstan: $43^{\circ} 24^{\prime} \mathrm{N} 75^{\circ} 2^{\prime} \mathrm{E}$, Dzhambulskaya oblast, $70 \mathrm{~km}$ NNE Frunze [Bishkek], $950 \mathrm{~m}$, rocky slope, 18-19.VII.1990 6 우 ad luc. L. Kaila \& K. Mikkola, leg. Genitalia slides: J. Junnilainen prep. no. 98041001, 98041301, 98041302, 98042301, 99031202, 99031203; J. Kullberg prep. no. 2/7.12.1999; J. Kyrki Slide 07.11.1983 prep. no. A 284 / J. K.; 4 further genitalia preparations preserved in glycerol. The paratypes are preserved in private collections of J. Junnilainen, J.-P. Kaitila, T. \& K. Nupponen as well as in the Zoological Museum, University of Helsinki, Finland.

Etymology. Latin, glaucus = bluish-grey. The species name alludes to the forewing scattered with fuscous scales, giving an impression of a bluish grey colour in fresh specimens.

Diagnosis. Externally S. glaucella sp. n. most resembles S. caesiella (Hübner, 1796) and $S$. compunctella (Herrich-Schäffer, 1851), but differs from those by the following details. Unlike other species of Swammerdamia and Paraswammerdamia, S. glaucella has bluish grey colour in the forewing with purplish brown colour in the forewing fascia. In the male genitalia the pointed apex in the valva, and the length of the aedeagus being twice the length of the valva separate $S$. glaucella from all other species of Swammerdamia and Paraswammerdamia. Although the similar shape of valva with a pointed apex is characteristic for the species of the genus Kessleria, the members of this genus always have 12-veined forewing and never completely fused $\mathrm{M} 3$ and $\mathrm{Cu} 1 \mathrm{~A}$. In the female genitalia the shape of caudal margin of lamella postvaginalis most resembles that of $S$. sedella Moriuti, 1977, but the ductus bursae is shorter and broader, and the corpus bursae lacks the signum in S. sedella.

Description. Wingspan 13-17 mm. Head and thorax pure white. Antenna grey, annulated with brown, scape pure white. Labial palpus whitish, basally with fuscous scales. Fore and mid legs dark fuscous, hind leg light greyish white. Abdomen grey, paler beneath. Forewing ground colour white, largely overlaid with blue shining fuscous scales; anteapical costal spot white, distinct antemedial fascia purplish brown; cilia fuscous, cilia line dark brown, cut by two white spots; in female forewing slightly shorter and broader, basally more whitish. Hindwing and cilia dark grey, hyaline patch absent.

Male genitalia (Figs. 2 and 3). Socii slender, nearly parallel, one minute spine at apex. Uncus 
Fig. 3. Swammerdamia glaucella sp. n., ơ genitalia (paratype, Russia S.Ural, Cheliabinsk distr. Prep. no. 98041302/Junnilainen), in lateral view.

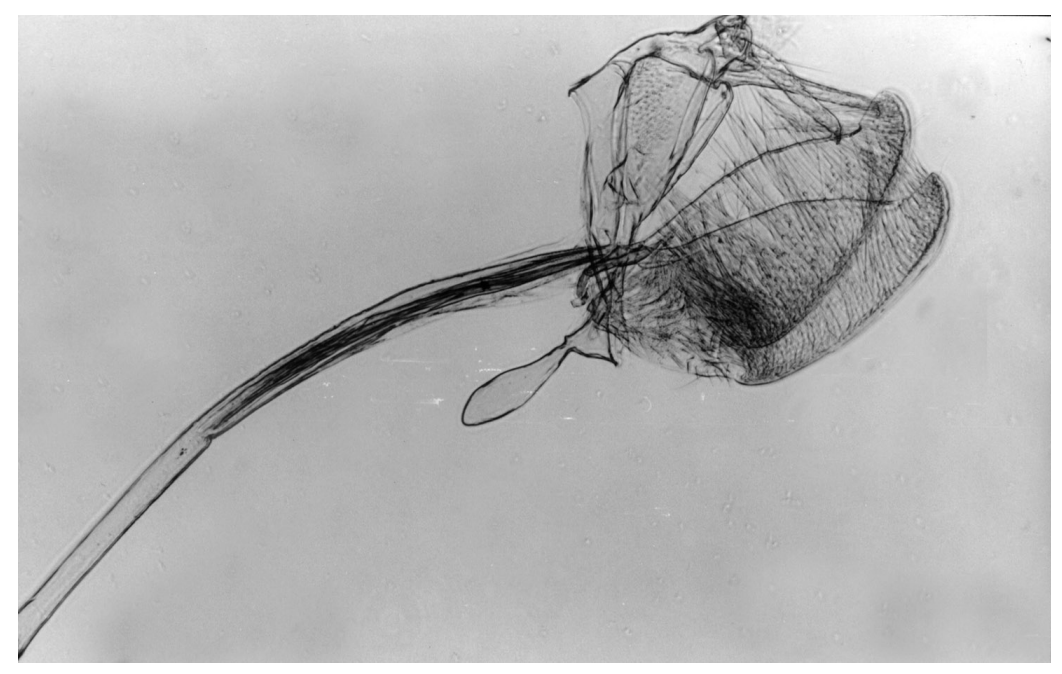

shallow, broad, well sclerotised. Ventral plate of gnathos angulate. Valva about twice as long as wide; costal margin bend; dorsal margin almost straight; sacculus well defined, almost separate plate; cucullus rounded with pointed apex. Saccus rather short, slightly dilated anteriorly, bowlshaped from lateral view. Aedeagus long and slender with distinct basal scape, about twice the length of valva, apex pointed with two long and narrow cornuti being more than half the length of aedeagus.

Female genitalia (Figs. 4 and 5). Caudal margin of lamella postvaginalis rather wide, concave. Antrum cup-shaped. Ductus bursae very long, narrow, membranous. Corpus bursae round with prominent, dentate signum.

Biology. Swammerdamia glaucella occurs in two generations from the end of May to the beginning of July and again late July. The species occurs in different kinds of xerothermic sites, like mixed forest, forest steppe with bush meadows, but also open steppe and rocky slopes. Dominant shrubs in such habitats are Spirea crenata, Spirea hypericifolia, Caragana frutex, Cotoneaster melanocarpus, and Lonicera ssp. The type material is mainly collected by artificial light, up to the altitude of $1200 \mathrm{~m}$. Immature stages remain unknown. However, S. glaucella could well be associated with Spirea or Cotoneaster since these plants are often abundant in the collecting sites of S. glaucella.

Distribution. Widely distributed in central part of Palaearctic region. Known from Russia (south-

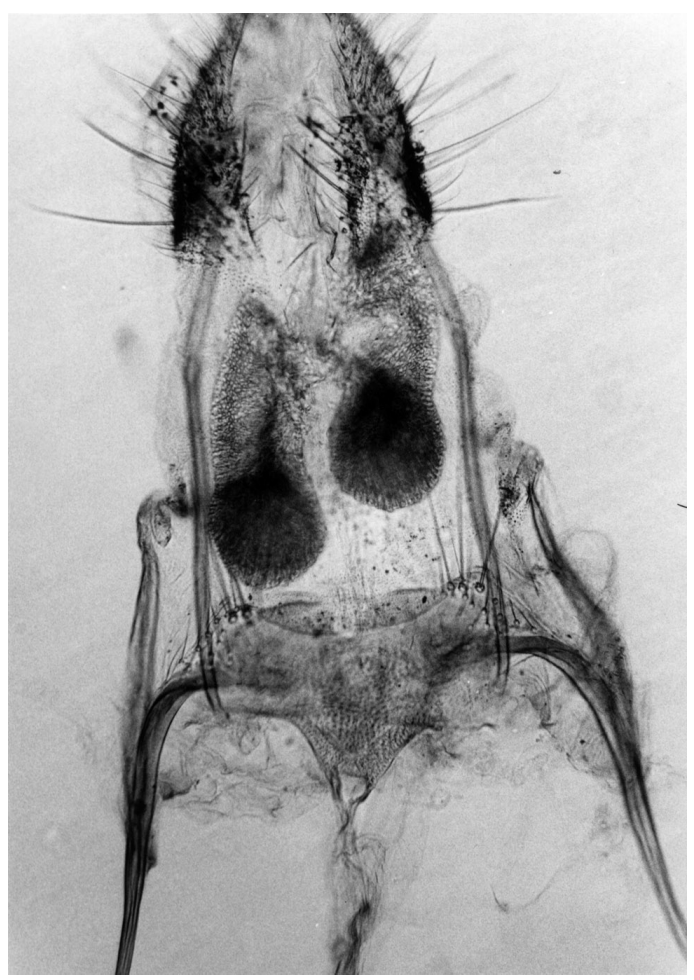

Fig. 4. Swammerdamia glaucella sp. n., o genitalia (paratype, Russia S.-Ural, Cheliabinsk distr. Prep. no. 99031203/Junnilainen), papillae anales and ostium bursae.

ern Ural Mountains, Tuva republic, Buryatia), SE

Kazakhstan and Mongolia.

Remarks. Kessleria caflischiella (Frey, 1880) 


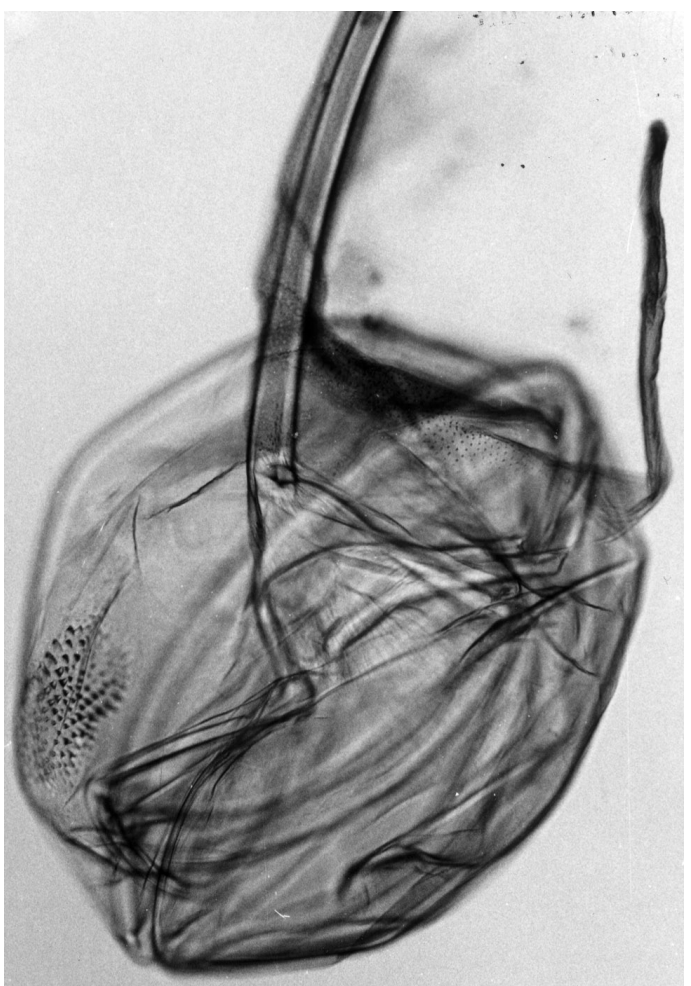

Fig. 5. Swammerdamia glaucella sp. n., o genitalia (paratype, Russia S.-Ural, Cheliabinsk distr. Prep. no. 99031203/Junnilainen), corpus bursae.

was recorded from Russia by Gershenson, 1980). However, the drawings of the imago as well as genitalia structures of both sexes presented by Gershenson (1980), do not agree with $K$. caflischiella in several crucial details (cf. Huemer \& Tarmann 1992, Parenti 2000), particularly the broader forewing and its different markings (e.g. forewing fascia of $K$. caflischiella is strongly oblique and does not contain any purplish brown colour). Moreover, K. caflischiella occurs in high altitudes in the Alps, while the Russian records come from lower altitudes in more xerothermic localities. The Russian records of $K$. caflischiella are obviously referable to Swammerdamia glaucella sp. n. whose male genitalia are superficially similar to those of $K$. caflischiella. These species can, however, be readily identified from each other by the broader forewing of S. glaucella with 11 veins, as compared to the narrow but 12 -veined

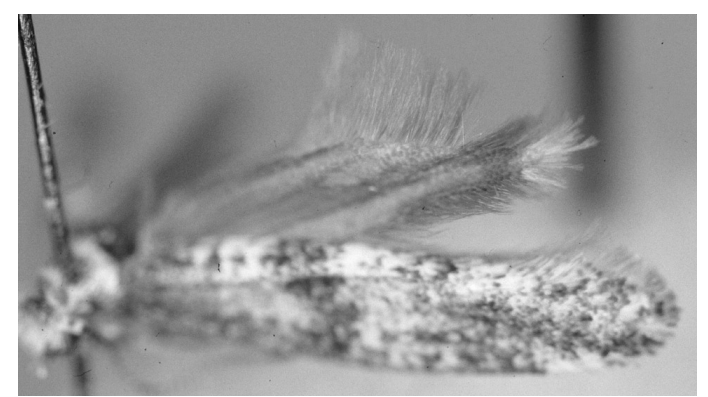

Fig. 6. Swammerdamia buraetella sp. n. on holotype.

forewing shape of $K$. caflischiella. These species can also be identified by the female signum which is present in S. glaucella, absent in K. caflischiella. Gershenson (1980) did not include the corpus bursae in the illustrations, but erroneously mentions in the text that the signum would be absent. Two specimens deposited in the Zoological Museum, St. Petersburg, determined as K. caflischiella by Gershenson have been confirmed to be $S$. glaucella (K. Nupponen pers. comm.).

\section{Swammerdamia buraetella $\mathrm{sp} . \mathrm{n}$.}

Type material: Holotype: $0^{7}$ (Fig. 6). Russia, Buryatia, 51 $40^{\prime} \mathrm{N} 107^{\circ} 20^{\prime} \mathrm{E}, 35 \mathrm{~km}$ SW UlanUde, Ivolginsk-Taphar $700 \mathrm{~m}$, steppe-hill, 17.VII.1996 J. Jalava \& J. Kullberg leg. Paratypes (41 O'రా, 9 OQP): with the same data as in holotype

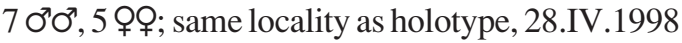

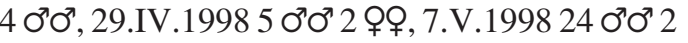
우, 8.V.1998 $10^{7}$ J. Kullberg leg. Genitalia slides: J. Junnilainen prep. no. 00012701, 00012702, 00012703, 00012802, 00012803, 00012804, 00012901, 00012902, 00012903 ; J. Kullberg prep. no. 1/7.12.1999; 2 further genitalia preparations preserved in glycerol. Holotype and the paratypes are preserved in the Zoological Museum, University of Helsinki, Finland.

Etymology. The species name is derived from Buryatia.

Diagnosis. S. buraetella most resembles $S$. pyrella (Villers, 1789), but differs from that externally by the distinct fascia on the forewing. In the male genitalia $S$. buraetella is characterised by the strongly pointed apex of valva, the similar 


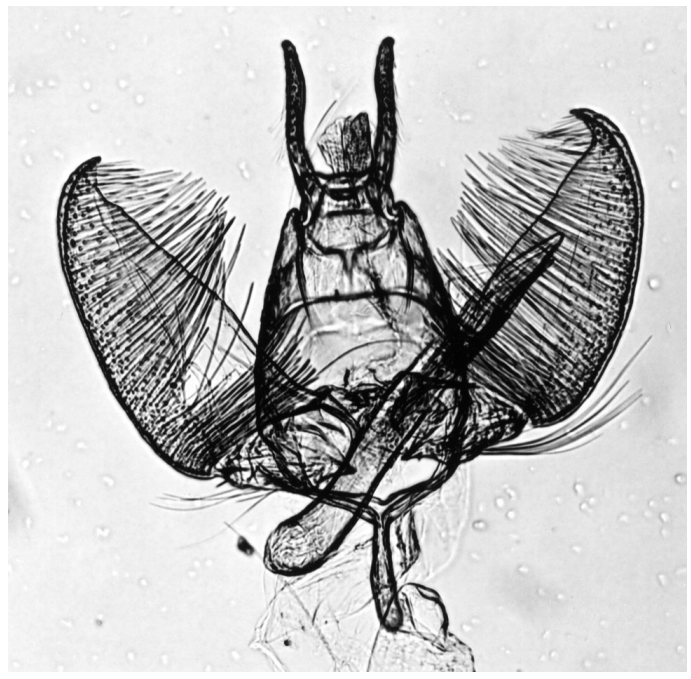

Fig. 7. Swammerdamia buraetella sp. n., ơ genitalia (paratype, Russia, Buryatia pr. Ulan-Ude. Prep. no. 00012701/Junnilainen).

detail of valva being absent from all other known Swammerdamia and Paraswammerdamia species. The female genitalia of $S$. bureatella also most resembles S. pyrella. S. buraetella has a wider, but not so developed caudal margin of lamella postvaginalis, ductus bursae is shorter without any sclerotization, and corpus bursae is larger and more rounded than in S. pyrella.

Description. Wingspan 10-12 mm. Head roughy, grey or whitish grey. Antenna grey, annulated with dark brown; scape not very long, covered with whitish scales. Labial palpus very short about same length as diameter of eye, dark brown, ringed with whitish in the middle and the apex. Tongue long, more than $3 \times$ length of labial palp, spirale. Thorax grey sometimes whitish grey. Fore and mid legs dark fuscous, mixed with white scales, hind leg whitish, faintly mixed with grey. Abdomen light grey, paler beneath. Forewing greyish-white; fuscous scales forming a distinct antemedian fascia; a white preapical costal spot; cilia fuscous; in female forewing slightly shorter and broader. Hindwing and cilia grey, without a hyaline patch.

Male genitalia.(Figs. 7 and 8). Socii narrow rather long, parallel, with one minute spine at apex. Tuba analis membranous. Uncus shallow, broad,

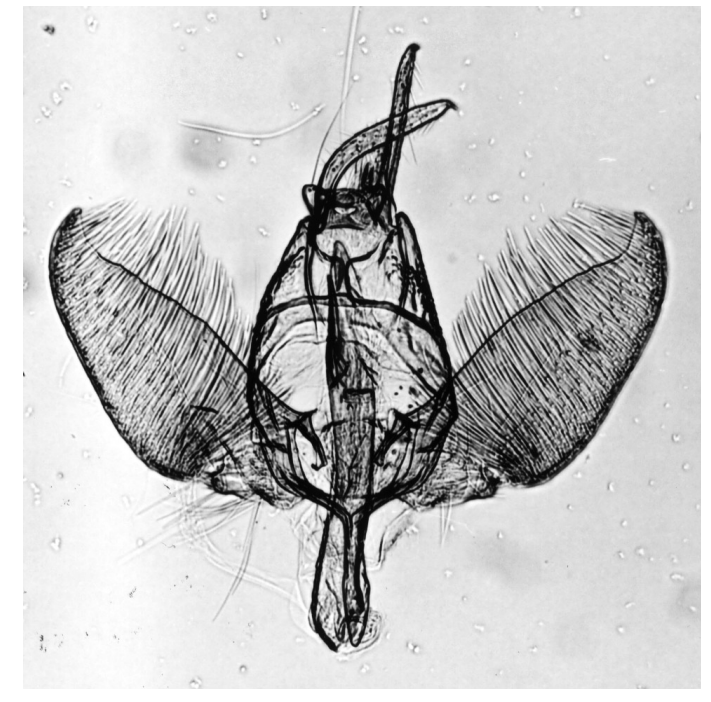

Fig. 8. Swammerdamia buraetella sp. n., ơ genitalia (paratype, Russia, Buryatia pr. Ulan-Ude. Prep. no. 00012703/Junnilainen).

well sclerotised. Arms of gnathos medially fused; gnathos not mesially differentiated. Valva slender, about $2.5 \times$ long as wide, narrowing toward apex; costal margin bend; dorsal margin almost straight; cucullus rounded with strongly pointed apex; sacculus well defined almost separate plate. Saccus rather short slightly dilated anteriorly. Aedeagus stout with basal scape, the same length as valva and $3 \times$ length of saccus; dorsally with carima formed of about seven massive horns of increasing length towards apex.

Female genitalia. (Fig. 9). Caudal margin of lamella postvaginalis wide and somewhat concave. Antrum cylindrical, sclerotized laterally. Ductus bursae relative short, membranous, gradually widening into a large corpus bursae. Corpus bursae large and rounded; signum rather large, an elliptical, concave, strongly dentate plate, horizontal dentation gradually stronger posteriorly.

Bionomy. Swammerdamia buraetella occurs in two generations from the end of April to the end of May and in July. The type material was collected by sweeping Spirea at dusk, and with artificial light at night. The habitat of the type locality is steep stony steppe slopes. Dominant shrubs are Spirea, Cotoneaster, Ulmus ssp., 


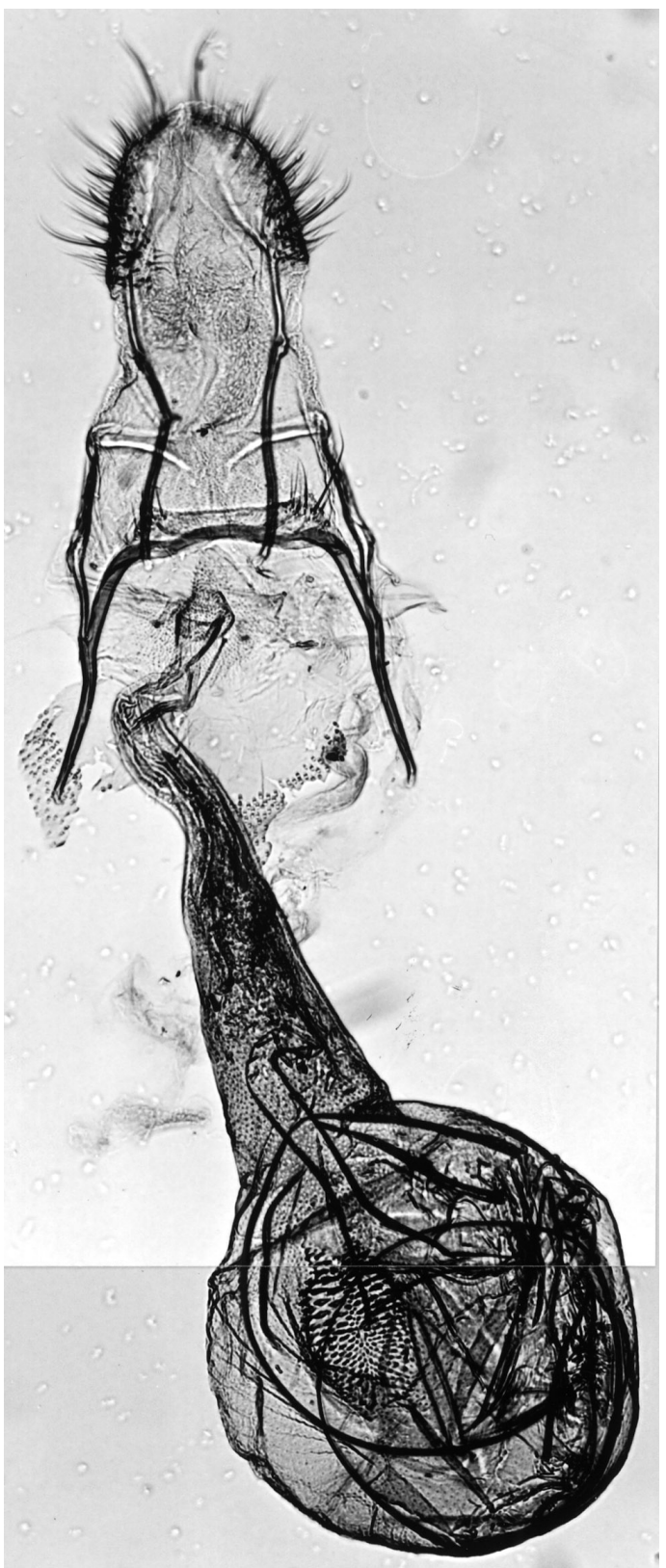

Fig. 9. Swammerdamia buraetella sp. n., o genitalia (paratype, Russia, Buryatia pr. Ulan-Ude. Prep. no. 00012702/Junnilainen).
Caragana frutex and Malus siberica. Immature stages remain unknown.

Distribution. Russia: Buryatia.

Acknowledgements. My thanks are due to the following entomological colleagues who have been on excursions with me or otherwise kindly helped me with this article: Vladimir Olschwang (Ekaterinburg, Russia), Yuri Mikhailov (Novouralsk, Russia), Alexander Malozemov (Ekaterinburg, Russia), Kari Nupponen (Espoo, Finland), Jari-Pekka Kaitila (Vantaa, Finland), Matti Ahola (Reisjärvi, Finland), Lauri Kaila (Helsinki, Finland), Jaakko Kullberg (Helsinki, Finland), Jukka Jalava (Helsinki, Finland), Helmut Steuer (Blankenburg, Germany), Bo Wikström (Nummela, Finland), Kimmo Silvonen (Espoo, Finland).

\section{References}

Eversmann, E. 1844: Fauna Lepidopterologica VolgoUralensis. - Casani Typis Universitatis. 633 pp.

Friese,G.1960: Revision der paläarktischen Yponomeutidae unter besonderer Berücksichtigung der Genitalien. Beitr. Entmol. 10: 1-131.

Gershenson, Z. S. 1980: A new for the USSR species of ermine moths of the genus Kessleria Now. (Lepidoptera, Yponomeutidae). — Ent. Obozr. 59: 855-857.

Gershenson,Z. S. \& Ulenberg, S. A. 1998: The Yponomeutinae (Lepidoptera) of the World exclusive of the Americas. - Koninklijke Nederlandse Akademie van Wetenschappen Verhandelingen Afdeling Natuurkunde, Tweede Reeks, Deel 99. 202 pp.

Huemer, P. \& Tarmann, G. 1992: Westpaläarktische Gespinstmotten der Gattung Kessleria Nowicki: Taxonomie, Ökologie, Verbreitung (Lepidoptera, Yponomeutidae). — Mitt. Münch. Ent. Ges. 81:5-110.

Meyrick, E. 1914: Hyponomeutidae, Plutellidae, Amphitheridae. — In: Wagner, H. (ed.), Lepidopterorum Catalogus 19. Berlin, pp. 1-64.

Moriuti, S. 1977: Fauna Japonica. Yponomeutidae s. lat. (Insecta: Lepidoptera). — Tafeln, Tokyo. 327 pp.

Parenti, U. 2000: A Guide to the Microlepidoptera of Europe. - Museo Regionale di Scienze Naturali Torino. $426 \mathrm{pp}$.

Steuer, H. 1993: Paraswammerdamia ruthiella nov. Spec., eine neue Yponomeutide (Insecta, Lepidoptera) aus dem Schwarztal bei Bad Blankenburg (Thuringen). Rudolstädter Nat. Hist. Schr. 5: 15-16. 